\title{
Self-help, marriage guidance and the making of the midlife crisis
}

\author{
Mark Jackson
}

\section{Introduction}

In 1965, the Canadian-born psychoanalyst and social scientist Elliott Jaques introduced a term - the midlife crisis - that continues to structure Western experiences and expressions of love and loss in middle age. Jaques's early work, carried out at the Tavistock Institute of Human Relations during the 1940s and 1950s, had focused primarily on the ways in which social systems operated as forms of 'defense against persecutory and depressive anxiety' among their members, as well as a mechanism for protecting the integrity of the system itself. ${ }^{1}$ During the following decades, Jaques became an influential figure in studies of bureaucracy, managerial accountability and leadership, as well as human capacity, work and social justice, introducing terms such as 'corporate culture' and 'requisite organisation' into discussions of occupational hierarchies and working practices. Jaques's contributions bridged a number of academic domains - including sociology, psychology, economics and applied research - but his theories of the interrelations between individual, institutional and social behaviour were connected through his preoccupations with time, creativity and trust. ${ }^{2}$

Although Jaques's sociological and psychological writings were plainly patterned by his empirical studies of organisations such as factories, churches and health services, they were also affected by his training and practice as a psychoanalyst and by the theories of Sigmund Freud, Melanie Klein and Wilfred Bion. These influences are 
particularly evident in his formulation of the midlife crisis. Jaques had begun to think about the concept in 1952 - at the age of 35 - during a period of personal reflection on the challenges of midlife. When he first presented the paper to the British Psychoanalytical Society in 1957 it generated only a muted response, and it was not published in the International Journal of Psycho-Analysis until eight years later. ${ }^{3}$ In the article, Jaques argued that during the middle years of life growing awareness of personal death precipitated a depressive crisis, masked by a manic determination to thwart advancing age:

The compulsive attempts, in many men and women reaching middle age, to remain young, the hypochondriacal concern over health and appearance, the emergence of sexual promiscuity in order to prove youth and potency, the hollowness and lack of genuine enjoyment of life, and the frequency of religious concern, are familiar patterns. They are attempts at a race against time. ${ }^{4}$

Jaques's formulation of the midlife crisis emerged primarily from studying what he referred to as 'a random sample' of over 300 'creative artists' - such as Mozart, Raphael, Rossini, Bach and Shakespeare who had either died in their mid- to late thirties or whose work had changed radically in volume or mode of expression during that period of their lives. ${ }^{5}$ Stimulated by contemporary interest in the physical, psychological and spiritual dimensions of ageing and death - evident in the emergence of geriatrics as a medical speciality on both sides of the Atlantic and in the proliferation of self-help guides to retaining the vitality of youth - biographical and autobiographical studies of 'the curve of life' were not unusual in the mid-twentieth century. ${ }^{6}$ In the 1920s, the American psychologist Granville Stanley Hall - renowned for his studies of both adolescence and old age - had substantiated his theory of a 'dangerous age' by recounting the emotional disturbances evident in the lives of middle-aged men as they faced the 'bankruptcy of some of their youthful hopes.7 Indeed, in a series of mini case studies that prefigured Jaques's approach, Hall referred directly to 'the middleage crisis' experienced by Nietzsche in his thirties. ${ }^{8}$ Similarly, Jung's central concept of individuation (or integration of the self), with its emphasis on development across the second half of life, was assembled by juxtaposing case histories, notions of an archetypal life course and reflections on his own midlife struggles to balance conflicting facets of 
his personality. ${ }^{9}$ What Jaques added to these earlier, largely descriptive accounts was a psychoanalytical framework that provided a basis for not only explaining, but also mitigating, the 'emotional impoverishment' and psychological imbalance that appeared to be characteristic of midlife crises. ${ }^{10}$

According to Jaques's wife and co-researcher, Kathryn Cason, it took twenty-five years for her husband's 'work on midlife crisis to be accepted." Although there is some, admittedly rather raw, evidence to support Cason's view that usage of the term only reached a peak in the $1990 \mathrm{~s},{ }^{12}$ it is nevertheless clear that Jaques's model of midlife as a tipping point in the life course soon captured the attention of psychologists, sociologists, self-help authors and journalists. From the late 1960s, it began to guide clinical approaches to understanding and resolving what became known as the 'search for meaning' that was thought to typify the midlife identity crisis. ${ }^{13}$ It also became a notable motif in the work of American researchers, who were developing a variety of ethnographic and survey techniques to evaluate the impact of life transitions on personal identity, health and well-being. ${ }^{14}$ The sense of inevitable crisis and decline that Jaques's concept was thought to carry was often contested, however, particularly by feminist authors who were keen to invert the negative connotations of the midlife crisis and focus instead on the potential for growth and self-fulfilment in women after midlife. ${ }^{15}$ In Britain, the perceived impact of midlife crises on marriage shaped efforts to address the personal, familial and social consequences of rising levels of divorce,${ }^{16}$ and inflected the psychoanalytical approaches to resolving marital tensions adopted by Henry V. Dicks and his colleagues at the Tavistock Clinic in London. ${ }^{17}$ The notion of crisis carried wider resonance as a tool for articulating the anguish of ageing. Jaques's depiction of the 'defensive fantasies', embraced by middle-aged men in particular, to forestall the effects of growing old, figured strongly in post-war literary and cinematic treatments of love and loss around midlife. ${ }^{18}$ In the novels of John Updike, Sloan Wilson, Simone de Beauvoir and Joseph Heller, or in Ingmar Bergman's film Scenes from a Marriage, the emotional turbulence of middle age provided the plot line for explorations of the interrelations between personal, marital and social crises. ${ }^{19}$

There have been some historical studies of the reception and diffusion of Elliott Jaques's psychoanalytical formulation of the midlife 
crisis, particularly in the context of subsequent feminist critiques of contemporary preoccupations with men at midlife. ${ }^{20}$ So far, however, historians have rarely focused on how Jaques's work drew on, and gained purchase from, earlier studies of the challenges of middle age written by the authors of self-help manuals and marital advice literature during the interwar and immediate post-war years. Although self-help and marriage guidance differed in many ways - one focusing largely on self-fulfilment, the other on marital or relational fulfilment - they also had much in common. Both were strongly gendered. According to selfhelp authors and some proponents of psychoanalytical approaches to marriage guidance, men's crises were primarily the product of psychological anxieties about work and death; by contrast, women's difficulties at midlife were interpreted as an inability to cope with, or to see beyond, menopause and the empty nest. In addition, self-help literature and marriage guidance both responded to, and helped to reconstitute, interwar and post-war pressures to restore political order and social stability in the face of economic recession, global conflict, failing marriages and the apparent disintegration of conservative norms and values. Effective social reconstruction, like the resolution of personal and marital tensions at midlife, demanded the realignment of individual, domestic, occupational and social selves and a reconfiguration, or rebalancing, of the needs of self and others in a climate of aggressive individualism. ${ }^{21}$ Self-help books and marriage guidance literature also reveal how the boundaries of middle age and the parameters of the midlife crisis were fluid and ambiguous, constructed by shifting configurations of the life course and prominent Western emphases on the correlation between personal prosperity, social harmony and economic productivity.

\section{Ambiguities of midlife}

According to Elliott Jaques, the midlife crisis was typically encountered by men and women in their mid-thirties. This critical age, he argued, constituted a pivotal, if equivocal, moment in the life course: 'The paradox is that of entering the prime of life, the stage of fulfilment, but at the same time the prime and fulfilment are dated. Death lies beyond. ${ }^{22}$ Jaques's identification of 35 as the age at which the future began to be eclipsed by the weight of the past and overshadowed by the spectre of death relied on a strict scriptural calibration of life expectancy. His 
normalising narrative of creativity and despair was informed by the opening stanzas of Dante's Divine Comedy, in which the narrator revisits an encounter with death that occurred precisely halfway along the biblical life span of three score years and ten. ${ }^{23}$ The 'beautiful lines' at the start of Inferno, wrote Jaques shortly before his death in 2003, 'melded with my own inner experiences of the midlife struggle with its vivid sense of the meaning of personal death. ${ }^{24}$ Pictured as a fulcrum situated midway between birth and death, or at the onset of middle age, Jacques's notion of the midlife crisis folded personal experience, literary metaphor and lessons from his psychoanalytical practice into a predictive model of psychological health across the life course.

In spite of Jaques's temporal precision, it is clear that the boundaries of middle age - and by inference the timing of the midlife crisis - were unstable. In an article on 'America's unknown middle-agers' published in the New York Times in 1956, the Chairman of the Joint Legislative Committee on Problems of the Aging, Thomas C. Desmond, explored the 'much misunderstood period' of middle age. Reversing contemporary emphases on 'decay and decline' through midlife, he argued, required creating a distinct medical speciality of 'mediatrics' - analogous to paediatrics and geriatrics - to 'blossom forth to care for middle-aged folks. ${ }^{25}$ As Desmond and others recognised, however, there was a major challenge involved in establishing a dedicated field of scientific and clinical enquiry of this nature: there was no single definition or agreed meaning for the term 'middle age. ${ }^{26}$ For some, middle age constituted a fixed period between 40 and $60 ;{ }^{27}$ for others it signified not a precise time period, but a set of life-course experiences - and often crises - related to balancing work, family and leisure and characterised by fatigue, discontent and boredom; for yet others, it constituted a phase of life in which mental vigour and flexibility began to deteriorate and the body's recuperative powers were increasingly compromised.

The cultural complexities and ambiguities of midlife and the relative invisibility of middle age, indicated in the writings of Desmond and others, have shaped the historiography of ageing. Just as mid-twentiethcentury scientists, clinicians and governments were more interested in the very young and the elderly than those in middle age, which was arguably the 'last portion of the life span to be discovered, ${ }^{28}$ so too historians have been slow to historicise midlife on its own terms, rather 
than as the silent sequel to youth or merely a prelude to old age. Recently, however, a number of key studies have begun to expose the social, cultural and political determinants of shifting representations of midlife and to open up questions about the diversity of experiences of middle age according to class, race and gender across the nineteenth and twentieth centuries. John Benson, Kay Heath, Patricia Cohen and Steven Mintz have done much to direct scholarly attention to the middle years of life and to expose many of the myths of ageing through adulthood, in both the past and present. ${ }^{29}$ The anthropological and cultural studies of Margaret Lock and Margaret Morganroth Gullette have also challenged beliefs in the biological inevitability of decline through the middle years, highlighting the ways in which narratives of ageing are themselves cultural fictions. ${ }^{30}$

Although they adopt distinct perspectives, historical, sociological and anthropological studies reveal the ways in which middle age has been measured and experienced variably in temporal, biological and social terms. Modern Western approaches to ageing have been dominated by chronology, characteristically distinguishing different life stages in terms of age boundaries or years lived. In the late nineteenth century, censuses regarded those between 30 and 50 years old as middle-aged but, as Benson has shown, increasing life expectancy and cultural resistance to the inevitability of decline helped to shift the lower limit of middle age from 30 to $40 .{ }^{31}$ In 1920, a report in the Lancet suggested that much 'misery and ill-health' could be avoided by compulsory medical examination for those around the age of 40, that is 'half-way through what we all hope will be our span of life. ${ }^{32}$ During subsequent decades, considerable advertising space was dedicated to selling products to people struggling to counter the 'middleaged spread' associated with complacency and self-indulgence and to alleviate their fear of reaching 40 - or 'forty-phobia' (see Figure 9.1). ${ }^{33}$ At the same time, the upper limit of middle age was stretched to 60 or 65. This framing of middle age as the years between 40 and 65 was not incompatible with Jaques's subsequent chronology of life transitions: a midlife crisis occurred characteristically in the mid to late thirties at the onset of middle age and was followed by another crisis at 'full maturity around the age of sixty-five. ${ }^{34}$

The passing of time was not the only measure of ageing, although it was perhaps the most commonly used across the twentieth century. As 


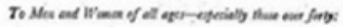 \\ Forty-phobia}

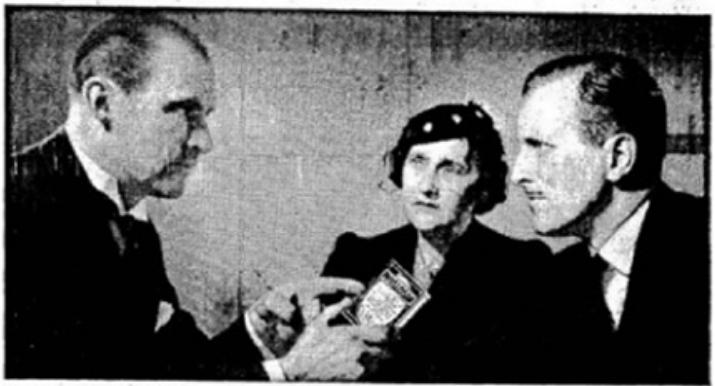

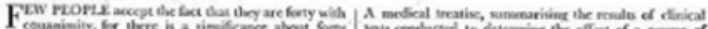
Fequaninity, for thore is a sipilifiance about Somy of youth, and the brexining of a pried of dover and

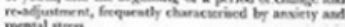

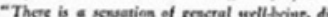
eptresance of mentel Jefresion end fectiog dis insurmownatakle fetigne, rebirm and incrinase of the

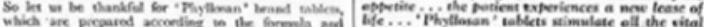

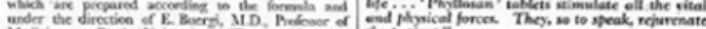

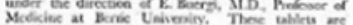

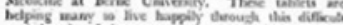

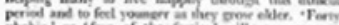

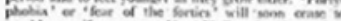
If yos ane freline your ase, if yos are randem,

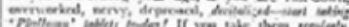

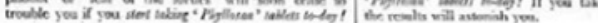

\section{Staut taking \\ Phyllosai tablets to-day!}

To revitalize your Blood, rejuvenate your Arteries, correct your Blood Pressure, fortify your Heart, strengthen your Nerves, and increase all your Physical and Vital Forces, irrespective of age!

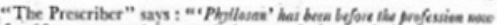

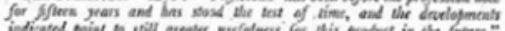

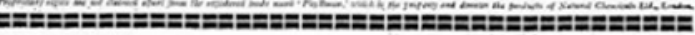

9.1 'Forty-phobia (fear of the forties)', The Times, 28 April 1938, p. 19 
some historians have indicated, the end of middle age in particular was often read in biological terms, particularly in women, whose middle years were reckoned by the ticking of a biological clock and whose later years were thought to be dominated, and in some cases disrupted, by the hormonal imbalances, physical changes and emotional unsteadiness associated with menopause. ${ }^{35}$ Men were also thought to experience a male menopause or climacteric, typified by declining virility and a range of psychological problems, but its more muted and extenuated character rendered it a less obvious determinant of midlife crises. ${ }^{36}$ However, the timing and experiences of biological transitions or crises across the life course were mediated by social and cultural norms. Margaret Lock, Judith Houck and Elizabeth Siegel Watkins have revealed how the manifestations of ageing and the 'change of life' in women and men were experienced, narrated and medicalised in line with culturally specific gendered notions of domestic duties and occupational aspirations and achievements. In women, the upper limit of middle age was marked not merely by menstrual changes, but also by the departure of children from the home (the 'empty nest syndrome'), or in some cultures by the transition from mother to grandmother. ${ }^{37}$ In men, by contrast, the boundaries of middle age were more often measured in terms of the onset, rhythms and cessation of working life and were largely bureaucratic conveniences associated with taxation, retirement and pension rights. ${ }^{38}$

The writings of Margaret Morganroth Gullette and others remind us that experiences of middle age are 'culturally patterned' and linked to a Western market economy that is dependent on sustaining the political and economic power of individuals across the life course. ${ }^{39}$ They also suggest that conceptualisations of midlife as a time of crisis presuppose certain constructions of selfhood. Margaret Lock's comparative studies of menopause in America and Japan indicate that Western accounts of ageing have tended to emphasise individual uniqueness and to valorise the pursuit of self-empowerment and personal agency. ${ }^{40}$ Indeed, twentieth-century models of midlife transition articulated by Carl Jung, Erik Erikson, Elliott Jaques, Daniel Levinson and Gail Sheehy focused on the ways in which crises could be harnessed to sculpt new identities, new healthier forms of 'self', although in doing so they generated fresh opportunities for conflict between competing individualities and temporalities within relationships and families. ${ }^{41}$ In contrast, Japanese 
models of socialisation towards maturity focused traditionally not on 'learning how to maximize one's own interests', but on becoming 'social and moral beings. ${ }^{\text {' }}$. At least before the gradual encroachment of Western family structures and values and the rise of individualism, Japanese narratives of midlife - which differed temporally between men and women - conveyed an alternative model of the self, one that was 'created and recreated in daily life, beyond and within the confines of the body, through committed participation in social life and through self-reflection' rather than self-interest. ${ }^{43}$ It was precisely the challenge of balancing the welfare of self and others, as well as coping with shifting experiences of time and identity across the life course, that preoccupied mid-twentieth-century authors of self-help and marriage guidance literature for the middle-aged.

\section{Life begins at 40}

In his early twentieth-century studies of 'senescence', or the last half of life, Granville Stanley Hall cited the work of the Danish author Karin Michaëlis as the origin of the term 'a dangerous age', which Hall took to mean the point in life when men were 'prone to weigh themselves in the balance' as death approached. ${ }^{44}$ What is interesting about Hall's appropriation of the term, given his almost exclusive emphasis on the creative crises of ageing men and shaped partly by his own experiences during middle age and on retirement in his seventies, ${ }^{45}$ is that Michaëlis's novel, The Dangerous Age - which was first published in Danish in 1910 and translated the following year into English - comprised letters and fragments from the diary of a 42 year-old woman, Elsie Lindtner. In narrating the emotional traumas of solitude and divorce in middle age, Michaelis drew attention to the painful 'years of transition' in women between 40 and 50: 'The time is gone by', Lindtner reflects in one journal entry. 'Life is over. ${ }^{46}$ According to Michaëlis, The Dangerous Age generated 'storms of abuse from the ranks of the radicals all over Europe', and the text also attracted a combination of acclaim and disapproval from American journalists. ${ }^{47}$ Contemporary outrage, particularly among suffragists, was partly triggered by Michaëlis's insistence that middle-aged women were unfit for office because of their biological limitations. From Michaëlis's perspective, the 'distressing enigmas of feminine psychology', which included a propensity for women to lie 
more often than men, stemmed from physiological imbalances and crises dictated not by their social status but by nature. ${ }^{48}$

There were, of course, alternative narratives of crises in the lives of women. In 1921, for example, the English novelist Rose Macaulay stressed the social, cultural and economic factors that shaped women's capacities to cope across the life course, not just at midlife. In what was regarded at the time as a riposte to Michaëlis's work, Macaulay's account of the lives of four women at different stages of the life cycle - written when she was in her late thirties - suggested that the absence of full voting rights and the lack of financial or professional independence meant that all ages were dangerous for women. ${ }^{49}$ Nevertheless, it is clear that the notion that midlife constituted a particularly critical stage of life gained considerable purchase immediately before and after the First World War. In Midstream, an autobiography published in 1914 when he was 35, the American author Will Levington Comfort referred to 'the restlessness and agony' experienced by many women at midlife when they realised that they had become strangers to their husbands and children. ${ }^{50}$ In men, a similar crisis was thought to be triggered by the tedium of working life: 'when twenty years of toil have come and gone', wrote Pastor Newell Dwight Hillis in Good Housekeeping Magazine in 1912, 'the work grows stale, the labor mechanical and meaningless, and the months become an endless round of hopeless repetition. During this 'dangerous age', he continued, both men and women turned to new sources of excitement, such as betting, gambling and reading sensational fiction, to combat the monotony of their lives. ${ }^{51}$

Widespread acceptance of the notion of a dangerous age was expedited by its use as a metaphor to capture the causes and consequences of global conflict and economic crisis. Citing H. G. Wells's prescription for salvaging Western civilisation from the wreckage of the First World War, Hall suggested that the human race had 'passed its prime' and that a 'new social consciousness' was required to steer the world into a healthier old age. ${ }^{52}$ American entry into the war had also provided the context for the emergence of more affirmative narratives of middle and old age, narratives that encouraged women and men actively to address and redress incipient physical and mental decline not merely for their own sake, but for the sake of their country. In an interview in The Pittsburgh Press published in April 1917, Mrs Theodore Parsons, the widow of an army officer, implored American women to 'train for the duties 
that war time may bring. ${ }^{53}$ Drawing on a wide range of evidence, including the work of Hall and her own experiences training pupils in schools and colleges, Parsons had for some years been advocating a particular form of 'New Education' that emphasised the role of physical exercise in developing the brain and balancing the emotions. ${ }^{54}$ In 1917, she argued that preparing for war duties was analogous to preparing for 'wifehood and motherhood' and demanded the same attention to physical training. Her comments were directed particularly at 'the adipose woman of forty' who had neglected to care for herself:

'It is a paradox of life,' Mrs. Parsons continued, 'that we do not begin to live until we begin to die. Death begins at thirty, that is, deterioration of the muscle cells sets in. Most old age is premature, and attention to diet and exercise would enable men and women to live a great deal longer than they do to-day. The best part of a woman's life begins at forty. ${ }^{55}$

Although applied explicitly to women in relation to wartime exigencies, Parson's phrase - 'life begins at 40' - was adopted as a catchphrase by American self-help authors hoping to check the loss of health and vitality associated with the stress of living through periods of economic depression. In 1932, Walter B. Pitkin, Professor in Journalism at Columbia University and author of numerous self-help guides between the 1920s and 1940s, used the phrase for the title of a popular book that promised readers an antidote to the seemingly inevitable downward curve of life after $40 .^{56}$ Enticing his audience with a vision of the excitement, joy and riches on offer in the 'Machine Age', which had reduced the 'hours of toil' and increased opportunities for leisure, Pitkin's prescription for happiness exploited belief in the American dream - the notion of freedom, upward mobility and self-made prosperity that had been articulated by James Truslow Adams in 1931 and subsequently translated into liberal capitalist commitments to self-governance and self-fulfilment. ${ }^{57}$

Although contemporary faith in self-improvement through material consumption had already been satirised in Sinclair Lewis's novel of 1922, Babbitt, ${ }^{58}$ the key message in Pitkin's work - that modern populations could now progress from 'making a living' to 'living' - proved attractive to aspiring middle-class middle-agers keen both to generate wealth and to display their well-earned capacity for leisure. Pitkin accepted that metabolism and energy decreased with age and that 
midlife transitions might be the result of 'some obscure shift in the endocrine balance. ${ }^{59}$ But he insisted that biological limitations need not prevent people from living more contentedly as they aged. The increased capacity to afford goods, pursue leisure activities and make the most of their time allowed the middle-aged to attain the 'emotional poise which underlies enduring happiness.' ${ }^{60}$ 'Happiness', Pitkin argued, 'comes most easily after forty. ${ }^{61}$

Pitkin's invocation to spend time and money wisely across the life course in order to prolong health and happiness was not merely a disinterested form of self-help; it was also a prescription for social stability and recovery from the Great Depression. Austerity and automation, he argued, had limited opportunities for young people to work and adversely affected their capacity to purchase either 'goods and services for simple subsistence' or those which helped 'towards selfimprovement both vocational and cultural. ${ }^{62}$ His manifesto for personal fulfilment in older age, along with the mantra that 'life begins at forty', was therefore underscored by a belief that economic growth depended primarily on harnessing the spending power, managerial capacities and wisdom of the middle-aged in order to expand employment prospects for the young, encourage independence and self-sufficiency, enable more people to work part-time, promote longer lives in better health and provide greater opportunities for leisurely 'self-realization. ${ }^{63}$

In 1965, Pitkin's son, Walter Pitkin Jr, reflected on the impact of his father's work. By focusing popular and professional attention on 'the subjective, or inner life of the middle-aged and aging person', he argued, Life Begins at Forty had encouraged readers to believe that life could be creative, happy and challenging after the onset of middle age, in the process launching 'a whole industry' of inspirational self-help literature for the middle-aged. ${ }^{64}$ As his son suggested, Pitkin was by no means the only writer of lifestyle manuals during the middle decades of the twentieth century. ${ }^{65}$ Books on diet, relaxation and yoga were sometimes marketed directly at those over 40 years of age to help them counter the effects of stress, tension, poor diet, lack of exercise, excessive work and inadequate rest that were thought to lead to nervous breakdowns and premature death. ${ }^{66}$ The belief that a full and happy life is a balanced one' figured strongly in these self-help texts. ${ }^{67}$ In their 1938 discussion of the merits of relaxation in a frenzied world where few could 'attain equilibrium', the British physician E. J. Boome and speech therapist M. 
A. Richardson emphasised the role of relaxation in achieving equanimity: 'The balance and stability which can be obtained by the practice of relaxation', they suggested, 'enables a man to face and deal fearlessly with responsibility and trouble instead of trying to evade them. ${ }^{68}$ The advice of the German-born American nutritionist Gayelord Hauser similarly focused on the manner in which readers could ensure good health across the life course, not only by adopting balanced diets, but also by balancing their personality, mind, activity, emotions, recreation, friends, budget and marriage. ${ }^{69}$

Arguments for prioritising leisure and relaxation as routes to happiness, or as mechanisms for balancing life in order to improve health across the life course, were restated by contemporary commentators on both sides of the Atlantic during the middle decades of the twentieth century. In a paper published in the American journal Marriage and Family Living, for example, Nadina R. Kavinoky, a Swiss-born gynaecologist and the first female president of the American National Council on Family Relations, claimed that individual and family mental stability depended on an appropriate mix of work, rest and recreation, a formula for health that also influenced post-war debates about safety and efficiency in transport industries. ${ }^{70}$ Recreation in particular, she argued, facilitated the rehabilitation of 'men wounded in body and spirit' and enhanced the capacity of couples and their children to cope with the physical and emotional demands of modern living. ${ }^{71}$ Yet, there were alternative approaches to healthy ageing that valorised work rather than leisure. Tom Lutz has pointed out that during the 1920s work was portrayed by American physicians and novelists as a solution to boredom and ennui, a means of invigorating mind and body, controlling or 'working through' emotions and realising the self. Men employed outside the home and housewives both needed work in order to foster feelings of self-worth: while for men satisfaction came from the office or factory, for women their 'real work was not the monotony of cleaning but the more significant, ennobling job of raising a family. ${ }^{72}$

Guidance about how to age well at midlife, and how to balance the competing demands of work, family and leisure, was therefore modulated by normative notions of gender. Although self-help authors framed their advice as if it applied equally to men and women, they nevertheless singled out for separate discussion the specific challenges faced by women, challenges that were partly linked to their distinctive 
domestic duties and social roles. The importance of achieving or maintaining a balanced life clearly structured recommendations for women's self-fulfilment in later life, as well as dictating debates about paid employment for women. ${ }^{73}$ According to the older Pitkin, wives and mothers whose children had left home and whose husbands were 'sunk deeply in the miry ruts of their own business offices' needed to identify educational and career opportunities that made use of their skills and experience in order to prevent boredom, unhappiness and periods of personal crisis. ${ }^{74}$ By contrast, college women - those educated in 'spinster factories' - needed to temper their commitment to work with more opportunities for play. ${ }^{75}$ Balancing their lives in these ways, Pitkin argued, would enable women in their forties and fifties to achieve a greater sense of utility and fulfilment in later years.

Although contemporary writers recognised the domestic and occupational determinants of well-being, interwar and post-war advice literature for middle-aged women, particularly in Britain, often focused on the biological changes associated with the menopause, which was thought to occur generally between the ages of 40 and 55. Self-help approaches to the menopausal years varied, not only in terms of weighing the physiological against the situational causes of menopausal difficulties, but also in terms of their empathy for middle-aged women. In a short book intended to reveal to both men and women the 'facts and fallacies of middle age', Joan Malleson, a clinical assistant in the Obstetric Unit at University College Hospital, explained that, although many menopausal symptoms were shaped primarily by hormonal imbalances - and in that sense might require treatment - popular accounts of 'the change' often exaggerated the sense of disruption, leading to unnecessary anxiety. ${ }^{76}$ Malleson's advice, like other studies of housewives and mothers experiencing menopausal anxieties, was aimed at reducing the impact of age-related biological and psychological changes on the health and self-esteem of the woman herself. Indeed, Malleson believed that the menopause need not constitute a crisis, or dangerous age, at all. ${ }^{7}$

In contrast to Malleson's emphasis on normalising menopause in order to minimise the personal distress of middle-aged women themselves, Kenneth C. Hutchin, the author of numerous self-help books written under the pseudonym 'A Family Doctor', drew attention to the negative impact of menopause on other members of the household: 
'The woman who makes the most of her symptoms', he wrote in 1963, 'can turn the climacteric into a time of misery for the whole family ... Whether it is in family life or in married life, women in the climacteric should try not to take things too seriously. ${ }^{\text {} 78}$ Hutchin's flippancy betrayed long-standing beliefs in the responsibility of wives and mothers to subjugate their own health concerns for the welfare of their families. His argument that menopause constituted a dangerous age not only for a wife and mother, but also more importantly for her husband and children, was not unusual, and was often repeated on both sides of the Atlantic. ${ }^{79}$ In the context of widespread concerns about rising levels of divorce and the breakdown of conventional social values before and after the Second World War, it was the potential for marriages and families to undergo a crisis that provided the framework for another form of mid-century lifestyle guidance that foregrounded relational, rather than individual, dimensions of midlife transitions.

\section{Fractured families}

In their wonderful study of the 'collision of interests between love, family and personal freedom, Ulrich Beck and Elisabeth BeckGernsheim argued that, in the twentieth century, 'deep cracks' appeared 'across the picture of the family. ${ }^{80}$ Situating the apparent 'chaos of love' in the context of new opportunities and pressures to 'break free and discover one's true self', Beck and Beck-Gernsheim regarded the midlife crisis as a marriage crisis, one made possible by the coincidence of three factors: individualization in general, female individualization in particular and increased life expectancy. ${ }^{\prime 1}$ Although, like Jaques, they considered the midlife crisis to be analogous to the adolescent pursuit of identity, Beck and Beck-Gernsheim understood the challenge of middle age not in terms of a growing awareness of personal death, but as a struggle for two individuals 'to survive within a shared life'. By disrupting the sense of stability and identity previously made possible by traditional gender roles and normative notions of the nuclear family, individualisation was encouraging men and women to escape from what were seen as the constraints of 'marital symbiosis. ${ }^{82}$

The image of fractured families was apt. Before the Second World War, no more than 7,000 couples were divorced in England and Wales annually. After the war, however, the number of divorces rose rapidly 
Table 9.1: Number of divorcing couples in England and Wales, 1945-85

Year

1945

1950

1955

1960

1965

1970

1975

1980

1985
Number of divorces

15,634

30,870

26,816

23,868

37,785

58,239

120,522

148,301

160,300

(Source: Office for National Statistics)

in Britain, reaching 37,785 by 1965 (see Table 9.1 ) ${ }^{83}$ A similar pattern emerged in North America, where a perceived crisis in marriage and family was regarded, already by the late 1930s, as equally serious as the crisis in the economic system and political order. ${ }^{84}$ A report on marriage and divorce statistics in the United States, published in 1973, highlighted a gradual rise in divorce across the first half of the twentieth century, a sharp peak immediately after the Second World War, and then another steady increase through the 1960s (see Figure 9.2). ${ }^{85}$

Contemporary commentators offered numerous reasons for these trends. The rise in divorces immediately after the war was explained as a 'symptomatic feature of the disturbance brought about by war in the field of family relations': extramarital affairs on the part of both men and women during long periods of separation and the challenges of readjusting to domestic life and civilian work created the conditions for the breakdown of relationships and families. ${ }^{86}$ But, as a number of government enquiries and commissions indicated, other factors may have contributed to the steady increase in rates of divorce across the post-war decades, particularly among those aged between 35 and 49. According to the British 1946 Denning Committee on Procedure in Matrimonial Causes, it was the exhausting 'mechanics of everyday life' that were reducing women's marital satisfaction and happiness in particular. ${ }^{87}$ Ten years later, the widely discussed Royal Commission on Marriage and Divorce suggested that friction between husbands and 


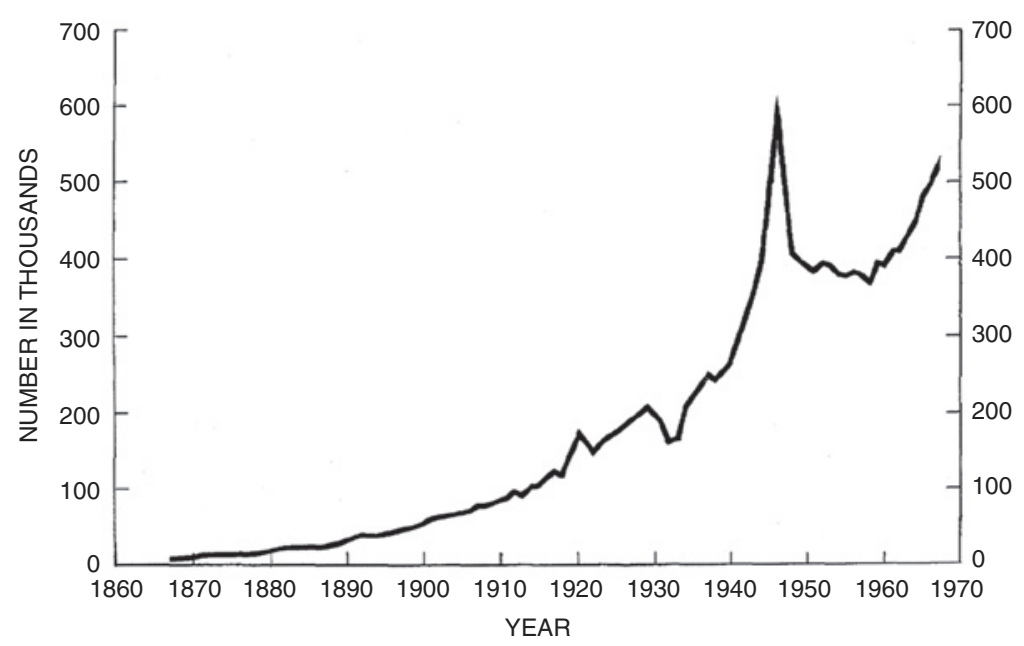

9.2 Divorces in the United States, 1867-1967 (Source: US Department of Health, Education and Welfare, 100 years of Marriage and Divorce Statistics: United States, 1867-1967 (Rockville, MD: Health Resource Administration, HRA 74-1902, 1973), p. 8

wives, and any resultant family instability, could be traced to socioeconomic factors such as 'the housing shortage, the earlier age of marriage, the higher standard of living, the transformation in the social position of women, and the change in attitudes towards non-marital sexual relations. ${ }^{88}$ The rapid increase in divorce rates was therefore regarded by some as an 'index of domestic decay' and the product of greater divorce-mindedness among post-war couples. ${ }^{89}$ Although many post-war British commentators, including Denning, emphasised the need for state-sponsored marriage guidance rather than easier divorce for couples struggling to 'deal with the post-marital causes of unhappiness, ${ }^{90}$ the Divorce Reform Act 1969 (and similar legislation in America and Canada) signalled a more permissive and less punitive approach to marital breakdown, leading to further dramatic increases in the number of divorces.

Divorce was also linked to the manner in which partnerships were supposedly being weakened by the atomistic tendencies of modern life, ${ }^{91}$ most notably 'the propensity to regard the assertion of one's own 
individuality as a right, and to pursue one's personal satisfaction, reckless of the consequences for others. ${ }^{\prime 92}$ As Beck and Beck-Gersheim's work demonstrates, contemporary focus on the role of individualism and self-realisation in promoting 'divorce-mindedness' has attracted the interest of scholars keen to explain the breakdown of relationships in terms of the internalisation of neo-liberal, consumer ideologies. However, any simplistic historical, sociological or economic emphasis on the threat posed to family stability by the rise of individualistic values can be contested. Jane Lewis's study of changing patterns of marriage and cohabitation suggests that selfish individualism, supposedly manifested in women's increased employment outside the family and in men's 'flight from commitment', has been assumed rather than demonstrated both in contemporary discussions of marriage and divorce and in historical accounts of changing family structures and values. $^{93}$

Lewis's contention that historians need to challenge ungrounded assertions about the sources of individualism and more carefully contextualise its impact on relationships is certainly valid. At the same time, overemphasis on the structural determinants of divorce or the macro-politics of Western individualisation fails to recognise fully the relational and family traumas associated with midlife marital tensions, or to appreciate the narrative devices and norms employed by marriage guidance counsellors and their clients to make sense of and alleviate the pain of betrayal, separation and divorce. Whether they were offered by state-supported marriage counsellors or by psychoanalysts at the Tavistock Clinic (initially funded privately, but later incorporated into the National Health Service), marriage guidance and couples counselling immediately before and after the Second World War were shaped by a recognition that the collapse of established relationships could be traced to a combination of family stresses, personality traits and ill health in middle age, as much as to the pursuit of self-fulfilment. Equally, routes to the resolution of marital differences or the reconfiguration of broken homes were not only fashioned by national campaigns for more effective regulation of marriage and divorce in order to rebuild family life and restore social stability after the Second World War; they were also determined by locally contingent strategies for mitigating the impacts of life transitions on the physical and emotional health of parents and children. ${ }^{94}$ 
The Marriage Guidance Council was founded in Britain by David Mace and his colleagues in order to 'promote successful marriage and parenthood' in the face of what Mace referred to, in deliberately sensationalist terms, as a 'marriage crisis." Although the initial idea for an organisation to ease 'marriages in trouble' had been formulated in 1938, the Council was formally established in 1942 and the first Marriage Guidance Centre opened in London the following year. ${ }^{96}$ Mace's belief in the importance of marriage in generating and maintaining social cohesion, and his conviction that divorce 'was nearly always the end of a long and sad story' that could have been avoided, were not the first articulations of a perceived need for effective marriage guidance. ${ }^{97}$ In a number of books published widely during the 1920s and 1930s, well before divorce rates began rising in Britain, Marie Stopes had offered marital advice not only to couples at the start of their relationships, but also to those in middle age whose marriages had become tinged by a 'common sadness. ${ }^{98}$ Rejecting contemporary fears that declining happiness within marriage was inevitable, Stopes advised readers on how to overcome the various physical and psychological obstacles to 'enduring passion' and lifelong contentment, framing her guidance in the relatively new language of endocrinology: women were vulnerable to disruptions to the 'harmony of the hormones' during menopause; and alterations in 'glandular secretions' could generate emotional crises in middle-aged men. ${ }^{99}$ In neither case, however, was it inevitable that 'the change' (or what Stopes also referred to as a 'critical period' or 'dangerous time') would prevent health and satisfaction in later life. ${ }^{100}$

Stopes regarded crises across individual life courses and in marriages as products of maladjustment and ignorance triggered by the 'artificiality of civilisation, a pessimistic refrain commonly articulated in the interwar years. ${ }^{101}$ In response, her prescription for promoting healthy ageing prioritised effective communication as a means of countering melodramatic media accounts of decline in middle and older age. ${ }^{102}$ While interwar advice literature focused primarily on individual strategies for self-fulfilment, Stopes approached marriage difficulties from a relational perspective, foregrounding the necessity for couples to learn about and help each other through troubled times. Similar arguments for recognising the needs of others permeated psychological understandings of marital difficulties in the interwar years. In 1938, William Brown, Director of the Institute of Experimental Psychology at the 
University of Oxford, suggested that successful adjustment to marriage - and indeed to middle age - required individuals to surrender 'the very pronounced degree of narcissism which we all have in our earlier years' and see life from the perspective of their partners. ${ }^{103}$

For marriage guidance counsellors - who included probation officers, social workers, nurses, occupational therapists and doctors - it was also the marital dyad that provided the principal focus for analysis and intervention. Indeed, some post-war counsellors explicitly acknowledged Stopes's relational approach: Mary Macaulay, a marriage counsellor in Merseyside, thanked Stopes (as well as Joan Malleson and David Mace) in the preface to her 1952 book The Art of Marriage, in which she argued that middle-aged couples needed to study and respond to 'each other's interests' if they were to avoid apathy and infidelity. ${ }^{104}$ The clearest example of the practical approaches to marital disharmony adopted by marriage counsellors - whose work was sometimes dismissed as a 'technique in search of a theory' ${ }^{105}$ - can be found in a study by J. H. Wallis and H. S. Booker, whose 1958 description of the National Marriage Guidance Council's work included the tabulation and analysis of the problems faced by couples, mostly middle-aged and middle class, who had consulted counsellors for help between 1952 and 1954. The significance of the couple was clear. Even when counsellors were approached by only one partner at a time of crisis, they were to remember that in marriage counselling there are no problems independently of the marriage, independently of husband and wife. ${ }^{106}$ After one or more individual consultations, counsellors were expected to invite the other partner to join them. ${ }^{107}$

The second section of Wallis and Booker's study illustrated the range of factors precipitating requests for help from the Marriage Guidance Council and situated marital problems in relation to the duration of marriage, the number of children and the ratio of wives to husbands who first sought guidance (57.5 per cent women; 37.5 per cent men; and 5 per cent together in 1952). The study also traced the outcomes of counselling, including the marriage difficulties being overcome (19 per cent), the relationship being improved (16.5 per cent) or showing no improvement ( 31.5 per cent). ${ }^{108}$ Wallis and Booker identified a variety of causes of crisis, including ill health, personal defects (such as selfishness, especially of the husband), parental interference, sexual difficulties and known or suspected infidelity, more often, but 
by no means exclusively, on the part of the husband. ${ }^{109}$ Marital difficulties experienced by couples were illustrated by abbreviated case studies that provided alternative perspectives on the critical period of middle age and marriage to those presented by self-help authors. As in Stopes's work, it was the relational and familial dimensions of crisis that emerged in condensed narratives of marital disharmony, revealing the assumptions and expectations that counsellors imported into encounters with clients. Descriptions of thirty-seven cases of infidelity of the husband and fifteen of the wife, often after many years of marriage, highlight the ways in which blame was apportioned and success measured in terms of continuation of the marriage. In one case, a marriage of thirty-one years and four children had ended when the husband left his wife to live with 'a third party', citing his wife's lack of affection and her tendency to talk 'like a parrot, never ending'. Another couple had been 'happy for fifteen years' before the husband - who was described as overbearing and cruel - had begun 'an affair with the widow of a friend. ${ }^{110}$

In 1963, Wallis drew further on his experiences of helping clients and their partners struggling with the challenges generated by 'the uncertainty of middle age. ${ }^{111}$ Like Jaques two years later, Wallis prefaced his work with the opening lines of Dante's Divine Comedy, equating the turbulence of midlife to the physiological and emotional transformations, as well as the defiant and narcissistic tendencies, associated with adolescence. ${ }^{112}$ Reflecting on how men and women coped during midlife with changes at home and work, with altering relationships and parenthood, and with the tensions involved in establishing and maintaining a partnership between two individuals (the 'Us' of marriage), Wallis set out what he regarded as one of the key symptoms and triggers of upheavals in middle age, whether within or outside marriage: 'The most startling is the sudden compulsive infidelity that not infrequently comes the way of the counsellor.' ${ }^{113}$ The abandoned partner, or 'the innocent party' in the eyes of the divorce laws, he explained, was shocked, bewildered and desolated by the loss of what had previously appeared to be a 'happy, normal, stable marriage. ${ }^{\text {'114 }}$ In a discussion that captured many mid-century anxieties about middle age, Wallis suggested that the psychological determinants and behavioural manifestations of the accompanying 'emotional typhoon', evident in both partners, constituted a 'middle-age crisis..'15 
The focus of marriage guidance counsellors on couples rather than individuals stemmed directly from the contemporary commitment of the state, as well as the Catholic and Anglican churches, to reinvigorating family life and restoring social order by strengthening marriage: marital stability was a precondition for national stability. ${ }^{116}$ According to the National Marriage Guidance Council, successful marriage, achieved only through 'unselfish love and self-discipline', was vital to social well-being. ${ }^{117}$ By contrast, as the Royal Commission on Marriage and Divorce had pointed out with concern in 1956, psychodynamic approaches to marital and midlife difficulties tended to ignore the significance of existing family relationships; instead, they focused on promoting self-expression and self-fulfilment through a process of prolonged individual psychoanalysis of the type used by Elliott Jaques to reveal the unconscious drivers of the midlife crisis. ${ }^{118}$ Yet not all psychotherapists neglected the relationship between partners or the dynamics of the family in seeking to resolve marital tensions, whatever their cause. One of the features of the social casework carried out by staff at the Family Discussion Bureau of the Tavistock Clinic was its emphasis not only on the dynamics of individual personality development, but also on the 'disturbances of emotional equilibrium' between two partners. ${ }^{119}$

Drawing on a combination of methods adapted from psychoanalysis, child guidance and the work of Michael Balint, caseworkers at the Bureau developed a team approach that focused not on 'the individual but the marriage, and behind it the family. ${ }^{120}$ Although caseworkers did see clients individually, particularly in the initial consultation or if a partner was reluctant to attend, emphasis on the couple as a single analytical unit prioritised involving both parties in addressing marital problems. The published, anonymised narratives of marital tensions presented by members of the Bureau were more detailed and more vivid than those provided by the National Marriage Guidance Council, but similarly revealed the web of norms and assumptions that structured couples therapy as well as the marital problems that it was designed to mitigate. Case reports of the Bureau's work with particular clients stretched over several pages, aiming to connect and make sense of the couple's family backgrounds, their courtship and marriage and the birth of their children, and to articulate current problems within the relationship from the perspective of each partner. As staff at the Bureau 
pointed out in an introduction to their techniques published in 1955, the purpose of discussing such issues openly was to enable the couple to address 'the vicious circles of intolerance and resentment' and to establish in their place a 'beneficent spiral' that ideally enabled the satisfaction of both husband and wife and facilitated the well-being of what the Bureau referred to as the 'primary family unit. ${ }^{121}$ Staff at the Bureau measured success in terms of improvements in marital and other relationships and in the adjustment of individuals to personal circumstances.

The value of joint, rather than merely individual, psychotherapy at the Tavistock was most forcefully articulated by Henry V. Dicks, whose study of marital tensions, published in 1967, set out the analytical principles and practices of marital therapy. Although Dicks criticised David Mace for his 'reliance on clichés', his analysis was similarly shaped by contemporary truisms about the importance of investigating 'disturbed marriages' in order to address the 'trail of unhappiness' generated by 'broken homes' after the Second World War. ${ }^{122}$ Dicks's approach, however, was more clearly structured by an understanding of the complex interrelations between cultural norms, social expectations, emotional growth and what he termed 'marital pathology.' ${ }^{123}$ Drawing on the findings from a pilot study initiated in 1949 and first published in 1953, Dicks developed a strategy for diagnostic interview and joint therapy that moved well beyond the dyadic approach advocated by marriage guidance counsellors. ${ }^{124}$ For Dicks, effectively working through and remedying relational tensions required establishing a novel system of joint interview and joint therapy involving both partners and two therapists. ${ }^{125}$ Over time, this 'four-person relationship', Dicks suggested, would allow couples, whether married or not, to uncover and address conflicts generated by disappointed role expectations, the power of past identifications and the projection of one partner's repressed needs or characteristics onto the other. ${ }^{126}$

Dicks acknowledged that factors other than those linked to personality and emotional immaturity impacted on marital harmony: marriages could become strained under the influence of in-laws, economic and housing difficulties, and clashes of culture. In addition, he argued, marriages contracted under certain forms of stress - such as 'a child on the way, the rebound from another affair, or as a desperate remedy for social loneliness' - were often doomed from the start. ${ }^{127}$ Such situational 
pressures were, of course, understood by marriage guidance counsellors such as Wallis to be key drivers of marital tensions, and often framed medical and popular advice to couples struggling to cope with the social and biological effects of ageing, the climacteric, emotional isolation and infidelity. Particularly poignant in this context are the stories of women on both sides of the Atlantic who sought to escape from domestic boredom, economic constraints and unhappy marriages by going out to work. ${ }^{128}$ However, unlike much marriage guidance literature aimed at the middle-aged, Dicks insisted that social circumstances still needed to be understood primarily along psychoanalytical lines - that is, "in terms of the meaning they have for the two intrapersonal worlds. ${ }^{129}$ Given his commitment to reading both individual and dyadic development in psychoanalytical terms, it is not surprising that Dicks was one of the first writers on marital stress and divorce among the middle-aged to cite Elliott Jaques's emphasis on understanding midlife transitions in terms of 'bio-psychological crisis points' triggered by an awareness of death. ${ }^{130}$

\section{Conclusion}

In The Normal Chaos of Love, Ulrich Beck and Elisabeth Beck-Gernsheim insisted quite rightly that the mid-life crisis is a social, not a natural event. ${ }^{\prime 13}$ During the middle decades of the twentieth century, breaking free to discover one's true self might have been posited by self-help authors as an individual journey of discovery, a path to happiness that necessitated sacrificing certain social commitments for personal biological and psychological fulfilment. But the pursuit of self-realisation at midlife and its manifestations in infidelity and marital disruption also conformed to 'a general imperative': the symptoms and social significance of marital decay were dictated by the contrasting domestic and occupational expectations of middle-aged men and women, by concerns about the fragmentation of families and its impact on social stability and cohesion, and by a competitive labour market that prioritised mobile and productive individuals across the life course, sometimes at the expense of stable family relationships. ${ }^{132}$ Individual and collective, private and public strategies for realising selfhood, sustaining marriages and coping with crises at midlife were interwoven and bounded by political, economic and cultural contingencies. 
The publication of Elliott Jaques's article in 1965 is often regarded as the moment of conception of the midlife crisis, as if it emerged de novo from Jaques's psychoanalytical practice and biographical study of creative artists. But, as this discussion of self-help literature and marriage guidance suggests, many of the key ingredients of Western narratives of middle age were well established by the early 1960s. Jaques's articulation of the emotional turbulence associated with the midlife search for meaning in the face of death was made possible by narrative traditions focusing on the tensions between individual freedom, marital harmony and social stability - already evident during the interwar and immediate post-war years. Similarly, academic acknowledgement of Jaques's ideas, and their incorporation into literary and cinematic sources during the 1970s and 1980s, was facilitated by widespread acceptance of the biological and psychological dimensions of midlife and marital crises that self-help authors and marriage counsellors had been addressing for some decades.

There were clear similarities between self-help and marriage guidance on both sides of the Atlantic, not only in terms of their scope and purpose, but also in terms of the ways in which their formulations of midlife and marriage often drew - like Jaques's work - on personal experiences of ageing. Both genres were also framed by shifting and contested notions of crisis, balance and selfhood, concepts that gained considerable social and cultural traction in the unstable years of economic depression, global conflict and social reconstruction before, during and after the Second World War. Yet, there were also differences between self-help and marriage guidance. Unlike the authors of advice literature for the middle-aged, who promoted self-realisation and selffulfilment, those involved in marriage guidance preferred to regard narcissism as an obstacle, rather than a pathway, to personal and conjugal happiness in later life. Coping with crises required adults to learn how to live together in a society supposedly weakened by individualisation and to effectively balance the needs of self and others, including not only partners but also children. ${ }^{133}$

In some cases, these seemingly contradictory messages - one focusing on balancing the self, the other on balancing the family - were juxtaposed in a single exposition of the route to health and happiness. In 1950, Gayelord Hauser's 'passport to a new way of life' included 
advice to readers to balance their diet, activity, mind and emotions at an individual level in order to achieve health and longevity; it also emphasised the need to 'give and take' in marriage, to recognise that, particularly in later years, marriage should be based on sharing 'mutual interests, mutual accomplishments, as well as mutual affection. ${ }^{134}$ Here, in a single text, Hauser had not only defined one of the central challenges of middle age in terms of the interactions between individual and social behaviour - a theme that ran through Elliott Jaques's work throughout the post-war years; he also articulated what had become a key paradox for those attempting to restore social and marital stability after the Second World War, namely how to balance - without eliding - the competing interests of the individual, the family and the state.

\section{Acknowledgements}

The research on which this chapter is based was generously funded by a Wellcome Trust Senior Investigator Award, 'Lifestyle, health and disease: changing concepts of balance in modern medicine', Grant No. $100601 / \mathrm{Z} / 12 \mathrm{Z}$. I would also like to thank Martin Moore for his astute comments on the first draft. As always, I am grateful to Siobhán, Ciara, Riordan and Conall for their love and support through my own midlife - and other - crises.

\section{Notes}

1 E. Jaques, The Changing Culture of a Factory (London: Tavistock Publications, 1951); E. Jaques, 'Social systems as a defence against persecutory and depressive anxiety', in M. Klein, P. Heimann and R. E. Money-Kyrle (eds), New Directions in Psychoanalysis (London: Tavistock Publications, 1955), pp. 478-98.

2 E. Jaques, The Form of Time (London: Heinemann, 1982); E. Jaques, 'On trust, good, and evil', International Journal of Applied Psychoanalytic Studies, 2 (2005), 396-403. Overviews of Elliott Jaques's life and work were published shortly after his death in a special issue of International Journal of Applied Psychoanalytic Studies, 2 (2005). See also S. Long, 'Organizational defenses against anxiety: what has happened since the 1955 Jaques paper', International Journal of Applied Psychoanalytic Studies, 3 (2006), 279-95. 
3 D. Kirsner, 'The intellectual odyssey of Elliott Jaques from alchemy to science', Free Associations, 11 (2004), 179-204. Kirsner's account draws heavily on conversations with Jaques.

4 E. Jaques, 'Death and the midlife crisis', reproduced in E. Jaques, Work, Creativity, and Social Justice (London: Heinemann, 1970), pp. 38-63, at p. 59.

5 Ibid., pp. 39-45.

6 C. Bühler, 'The curve of life as studied in biographies', Journal of Applied Psychology, 18 (1935), 405-9. On the history of ageing, geriatrics and anti-ageing therapies, see: S. Ottoway, 'Medicine and old age', in M. Jackson (ed.), The Oxford Handbook of the History of Medicine (Oxford: Oxford University Press, 2011), pp. 338-54; J. Stark, 'The age of youth', Lancet, 388 (2016), 2470-1; and K. Heath, Aging by the Book: The Emergence of Midlife in Victorian Britain (New York: State University of New York Press, 2009).

7 G. Stanley Hall, 'The dangerous age', Pedagogical Seminary, 28 (1921), 275-94. See also G. Stanley Hall, Senescence: The Last Half of Life (New York: D. Appleton and Company, 1922).

8 Hall, 'The dangerous age', p. 290.

9 For Jung's theory of individuation, see: C. G. Jung, Modern Man in Search of a Soul (London: Kegan, Paul, Trench, Trubner and Co., 1933); C. G. Jung, The Integration of the Personality (London: Kegan, Paul, Trench, Trubner and Co., 1940).

10 Jaques, 'Death and the midlife crisis', p. 59.

11 Cason is cited in Jaques's obituary in Business Wire (14 March 2003), available at www.businesswire.com/news/home/20030313005534/en/ OBITLeading-Psychologist-Century-Dr.-Elliott-Jaques-Dies, accessed 21 July 2017.

12 See, for example, the rising frequency of references to the midlife crisis in English language books through the 1980s and 1990s in Google NGram Viewer, available at https://books.google.com/ngrams/graph?content $=$ midlife + crisis\&year_start $=1800 \&$ year_end $=2000 \&$ corpus $=15 \&$ smoo thing $=3 \&$ share $=\&$ direct_url $=t 1 \% 3 \mathrm{~B} \% 2 \mathrm{Cmidlife} \% 20 \mathrm{crisis} \% 3 \mathrm{~B} \% 2 \mathrm{Cc} 0$, accessed 21 July 2017.

13 E. Sherman, Meaning in Mid-Life Transitions (New York: State University of New York Press, 1984), p. 221.

14 B. Fried, The Middle-Age Crisis (New York: Harper and Row, 1967); G. Sheehy, Passages: Predictable Crises of Adult Life (New York: E. P. Dutton, 1974); H. Schreiber, Midlife Crisis: Die Krise in der Mitte des Lebens (Munich: C. Bertelsmann, 1977); G. E. Vaillant, Adaptation to Life (Boston MA: Little, Brown, 1977); H. Still, Surviving the Male Mid-Life 
Crisis (New York: Thomas Y. Crowell, 1977); N. Mayer, The Male MidLife Crisis: Fresh Starts After Forty (New York: Doubleday, 1978); D. J. Levinson, The Seasons of a Man's Life (New York: Alfred A. Knopf, 1979); R. A. Segalla, Departure from Traditional Roles: Mid-Life Women Breaking the Daisy Chains (Ann Arbor, MI: UMI Research Press, 1979); J. Conway and S. Conway, Women in Midlife Crisis (Wheaton, IL: Tyndale House, 1983); A. Lawson, Adultery: An Analysis of Love and Betrayal (New York: Basic Books, 1988).

15 S. Schmidt, 'The feminist origins of the midlife crisis', Historical Journal, 61 (2018), 503-23. As Schmidt shows elsewhere, the feminist perspective on midlife transitions was also contested and often unfairly dismissed by psychologists: S. Schmidt, 'The anti-feminist reconstruction of the midlife crisis: popular psychology, journalism and social science in 1970s USA', Gender and History, 30 (2018), 153-76.

16 D. R. Mace, Marriage Crisis (London: Delisle, 1948).

17 H. V. Dicks, Marital Tensions: Clinical Studies towards a Psychological Theory of Interaction (London: Routledge and Kegan Paul, 1967), pp. 223-5.

18 M. M. Gullette, Safe at Last in the Middle Years: The Invention of the Midlife Progress Novel (Berkeley: University of California Press, 1988).

19 For post-war literary formulations of crises across the life course, some of which refer directly to the midlife crisis and most of which explore love, infidelity and betrayal in middle age, see: J. Updike, Rabbit, Run (New York: Alfred A. Knopf, 1960); J. Updike, Rabbit Redux (New York: Ballantine Books, 1971); J. Updike, Rabbit is Rich (New York: Ballantine Books, 1981); J. Updike, Rabbit at Rest (New York: Ballantine Books, 1990); S. Wilson, The Man in the Gray Flannel Suit (New York: Simon \& Schuster, 1955); S. Wilson, The Man in the Gray Flannel Suit II (New York: Arbor House, 1984); S. de Beauvoir, The Woman Destroyed (New York: G. P. Putnam's Sons, [1967] 1979); I. Bergman, Scenes from a Marriage (AB Svensk Filmindustri, 1973). On American cinematic treatments of the aspirations and disappointments of middle-aged men and women, see J. Levinson, The American Success Myth on Film (Basingstoke: Palgrave Macmillan, 2012).

20 Schmidt, 'The feminist origins of the midlife crisis'; Schmidt, 'The antifeminist reconstruction of the midlife crisis'.

21 Or what Ulrich Beck and Elisabeth Beck-Gernsheim have referred to as an 'ego epidemic': U. Beck and E. Beck-Gernsheim, The Normal Chaos of Love (Cambridge: Polity Press, 1995), p. 4.

22 Jaques, 'Death and the midlife crisis', p. 48. 
23 The opening stanza has been variably translated, but Jaques's version read: 'In the middle of the journey of our life, I came unto myself in a dark wood where the straight way was lost.' See E. Jaques, The Life and Behavior of Living Organisms: A General Theory (Westport, CT: Praeger, 2002), p. 3. Dante was in his late thirties when he wrote this passage, and elsewhere referred to the normative biblical lifespan of seventy years see R. M. Durling (ed.), The Divine Comedy of Dante Alighieri, Volume I: Inferno (Oxford: Oxford University Press, 1996), p. 34.

24 Jaques, The Life and Behavior of Living Organisms, p. 3.

25 T. C. Desmond, 'America's unknown middle-agers', New York Times, 29 July 1956, pp. 5, 42-3.

26 See, for example, D. B. Bromley, 'Middle age: an introduction', in R. Owen (ed.), Middle Age (London: BBC, 1967), pp. 7-21.

27 The notion of a 'fixed period' drew partly on William Osler's belief that great advances were only made between the ages of 25 and 40, that men over 40 were comparatively useless, and that men above 60 should retire - W. Osler, 'The fixed period', in Aequanimitas (Philadelphia: P. Blakiston's Son and Co., 1910), pp. 389-411. Osler's work formed one of the starting points of G. Stanley Hall's studies of ageing - Hall, 'The dangerous age.'

28 M. Lock, 'Deconstructing the change: female maturation in Japan and North America', in R. A. Schweder (ed.), Welcome to Middle Age! (And Other Cultural Fictions) (Chicago: University of Chicago Press, 1998), pp. $45-74$, at p. 45.

29 J. Benson, Prime Time: A History of the Middle Aged in Twentieth-Century Britain (Harlow: Addison Wesley Longman, 1997); Heath, Aging by the Book; P. Cohen, In Our Prime: The Invention of Middle Age (New York: Scribner, 2012); S. Mintz, The Prime of Life: A History of Modern Adulthood (Cambridge, MA: Belknap Press, 2015).

30 M. Lock, Encounters with Aging: Mythologies of the Menopause in Japan and North America (Berkeley: University of California Press, 1993); M. M. Gullette, Declining to Decline: Cultural Combat and the Politics of the Midlife (Charlottesville: University Press of Virginia, 1997); M. M. Gullette, Aged by Culture (Chicago: University of Chicago Press, 2004).

31 Benson, Prime Time, pp. 8-12. For contemporary reference to middle age as the years between 35 and 50, see Active 54, 'The middle-aged man and the war', Lancet, 184 (5 September 1914), 667-8.

32 'A medical survey at middle age', Lancet, 195 (1 May 1920), 974. A correspondent to the same journal agreed that 'the downward curve of life' began after the age of 35 or 40 - Aetas, 'Age and pensions', British Medical Journal, 1 (12 February 1921), 249-50. 
33 Phyllosan promised readers that they would 'feel younger as they grow older' - 'Forty-phobia (fear of the forties)', The Times, 28 April 1938, p. 19. For a discussion of advertisements and the growing use of terms such as 'middle-aged spread', see Benson, Prime Time, pp. 9-10, 17-18.

34 Jaques, 'Death and the midlife crisis', p. 38.

35 On the medicalisation of menopause, see: Lock, Encounters with Aging; J. A. Houck, Hot and Bothered: Women, Medicine, and Menopause in Modern America (Cambridge, MA: Harvard University Press, 2006); L. Foxcroft, Hot Flushes, Cold Science: A History of the Menopause (London: Granta, 2009).

36 E. Siegel Watkins, 'The medicalisation of the male menopause in America', Social History of Medicine, 20 (2007), 369-88; H.-G. Hofer, 'Medicine, aging, masculinity: towards a cultural history of the male climacterium', Medizinhistorisches Journal, 42 (2007), 210-46; H.-G. Hofer, 'Men in the critical age: Kurt Mendel and the controversy over the male climacteric', Urologist, 50 (2011), 839-45.

37 Lock, Encounters with Aging; Houck, Hot and Bothered; Watkins, 'The medicalisation of the male menopause'.

38 According to the American psychologist Bernice Neugarten, men perceived 'a close relationship between life-line and career-line' - B. L. Neugarten, 'The awareness of middle age', in B. L. Neugarten (ed.), Middle Age and Aging: A Reader in Social Psychology (Chicago: University of Chicago Press, 1968), pp. 93-8, at p. 96. For discussion of definitions of age in terms of the bureaucratic processes involved in distributing government pensions, see C. Port, “'Ages are the stuff!": The traffic in ages in interwar Britain', NWSA Journal, 18 (2006), 138-61.

39 R. A. Schweder, 'Introduction: welcome to middle age', in Schweder (ed.), Welcome to Middle Age!, pp. ix-xvii.

40 Lock, 'Deconstructing the change'.

41 On the inevitability of collisions created by competing individualities in relationships, making love 'more difficult than ever', see Beck and BeckGernsheim, The Normal Chaos of Love, pp. 52-6. For a discussion of divergences between individual, family and historical time, see T. K. Hareven, 'Family time and historical time', Daedalus, 106 (1977), 57-70.

42 Lock, 'Deconstructing the change', p. 60.

43 Ibid., pp. 60-1, 65-8.

44 Hall, 'The dangerous age', pp. 275, 287.

45 T. R. Cole, 'The prophecy of Senescence: G. Stanley Hall and the reconstruction of old age in America', Gerontologist, 24 (1984), 360-6.

46 K. Michaëlis, The Dangerous Age: Letters and Fragments from a Woman's Diary (New York: John Lane, 1911), available on the Project Gutenberg 
website, www.gutenberg.org/files/14187/14187-h/14187-h.htm, p. 25, accessed 16 September 2016.

47 A. Tridon, 'Author of the latest "daring" novel is in America', New York Times, 16 July 1911, Magazine Section, p. 9.

48 K. Michaëlis, 'Why are women less truthful than men?', Munsey's Magazine (May 1913), pp. 185-8; K. Michaëlis, 'Why are women less truthful than men?', Munsey's Magazine (June 1913), pp. 343-5. Michaëlis continued to enrage American women in particular with her views on their 'selfish, vain and arrogant' personalities - 'Insults American women: articles by Mme. Michaëlis called “international scandal”', New York Times, 2 August 1914, p. 11. According to Hall, Michaëlis was regarded 'as a traitor to her sex' - Hall, Senescence, p. 29.

49 R. Macaulay, Dangerous Ages (London: Collins, 1921). For a discussion of Macaulay's work, see Port, "'Ages are the Stuff!"'.

50 W. Levington Comfort, Midstream: A Chronicle at Halfway (New York: George H. Doran, 1914), p. 293. Helen Keller, an American author and political activist, used the same metaphor to narrate her life: $\mathrm{H}$. Keller, Midstream: My Later Life (New York: Doubleday, Doran and Co., 1929).

51 N. D. Hillis, 'The dangerous age in man', Good Housekeeping Magazine, 54 (1912), 537-40. The peculiar challenges of middle age also figured in medical commentaries exploring the role of diet and exercise in maintaining health through midlife. See: 'Middle age and old age', British Medical Journal, 2 (10 July 1915), 57-8. The article was reviewing S. Taylor, Health for the Middle-Aged (London: Methuen, 1915).

52 Hall, Senescence, pp. 30-1, citing H. G. Wells, The Salvaging of Civilisation: The Probable Future of Mankind (London: Cassell, 1921). Contemporaries also used the notion of salvage to describe approaches to improving the lives of the elderly - see L. J. Martin and C. de Gruchy, Salvaging Old Age (New York: Macmillan, 1930).

53 N. Greeley-Smith, 'Now is the time for all women to train for the duties that war time may bring', The Pittsburgh Press, 10 April 1917, p. 20.

54 Mrs T. Parsons, Brain Culture through Scientific Body Building (Chicago: American School of Mental and Physical Development, 1912). Parsons later published an abridged version for 'use in homes, schools and colleges' - Mrs T. Parsons, Making the Body Think (New York: Kelmscott Press, 1926).

55 Greeley-Smith, 'Now is the time for all women'.

56 W. B. Pitkin, Life Begins at Forty (New York: McGraw-Hill, 1932).

$57 \mathrm{~J}$. Truslow Adams, The Epic of America (Boston, MA: Little, Brown, and Company, 1931), pp. 415-16. 
58 S. Lewis, Babbitt (Leipzig: Bernhard Tauchnitz, 1922). The term 'Babbittry' became popular in America as a descriptor of narrow-minded materialism.

59 Pitkin, Life Begins at Forty, pp. 7, 24.

60 See Chapter 2 by Martin Moore for a discussion of contemporary commitments to emotional management in configuring health.

61 Pitkin, Life Begins at Forty, pp. 106-7. Pitkin stressed in particular the value of time: 'Time is neither a medium nor is it exchangeable', he wrote. 'It is the inmost stuff of life itself' - ibid., p. 86.

62 Ibid., p. 149.

63 Ibid., pp. 49, 107.

64 W. Pitkin Jr, Life Begins at Fifty (New York: Simon \& Schuster, 1965), pp. 21-2.

65 S. Currell, 'Depression and recovery: self-help and America in the 1930s', in D. Bell and J. Hollows (eds), Historicizing Lifestyle: Mediating Taste, Consumption and Identity from the 1900s to 1970s (Aldershot: Ashgate, 2006), pp. 131-44.

66 E. Jacobson, You Must Relax: A Practical Method of Reducing the Strains of Modern Living (New York: McGraw-Hill, 1934); G. Hauser, Look Younger, Live Longer (London: Faber \& Faber, 1950); N. Phelan and M. Volin, Yoga Over Forty (New York: Harper \& Row, 1965); D. Dunne, Yoga for Everyman: How to Have Long Life and Happiness (London: Gerald Duckworth, 1951). On therapeutic relaxation in mid-twentieth-century Britain, see Chapter 6 by Ayesha Nathoo.

67 N. Brierley, Relaxation for Men: Tension in Modern Living (London: Ward Lock, 1965), p. 7.

68 E. J. Boome and M. A. Richardson, Relaxation in Everyday Life (London: Methuen, 1938), pp. 1, 99.

69 Hauser, Look Younger, Live Longer, pp. 188-97.

70 N. R. Kavinoky, 'A balanced life for mental health', Marriage and Family Living, 6 (1944), pp. 41-2, 58, 64. On the impact of these debates on regulating duty rosters in the airline industry, see Chapter 7 by Natasha Feiner.

71 Kavinoky, 'A balanced life for mental health'.

72 T. Lutz, "Sweat or die”: the hedonization of the work ethic in the 1920s', American Literary History, 8 (1996), 259-83.

73 F. Cooper, 'Medical feminism, working mothers, and the limits of home: finding a balance between self-care and other-care in cross-cultural debates about health and lifestyle, 1952-1956', Palgrave Communications, 2(2016), article 16042, available at www.nature.com/articles/ palcomms201642, accessed 8 August 2017. 
74 Pitkin, Life Begins at Forty, pp. 112-20.

75 Ibid. Pitkin's son also recognised the specific problems of middle-aged women: Pitkin Jr, Life Begins at Fifty, pp. 16, 211-13.

76 J. Malleson, Change of Life: Facts and Fallacies of Middle Age (London: Penguin, [1949] 1963), pp. 13-18. For Malleson's work on hormonal balance and menopause, see: J. Malleson, 'An endocrine factor in certain affective disorders', Lancet, 262 (25 July 1953), 158-64; J. Malleson, 'Climacteric stress: its empirical management', British Medical Journal, 2 (15 December 1956), 1422-5.

77 M. C. Stopes, Change of Life in Men and Women (London: Putnam, 1936), pp. 1-21. For an international study of 'disturbances of equilibrium' in mothers and housewives during the 'most difficult years' of the menopause, see Mrs O. van Andel-Ripke, 'Mother and housewife in the climacteric', in Medical Women's International Association, The Menopause (Rome: Edizioni Minerva Medica, 1954), pp. 93-8.

78 K. C. Hutchin, The Change of Life (London: W. \& G. Foyle, 1963), pp. 67-9.

79 Houck, Hot and Bothered, pp. 114-32.

80 Beck and Beck-Gernsheim, The Normal Chaos of Love, p. 45.

81 Ibid., p. 68.

82 Ibid., pp. 66-7, 72.

83 Office of National Statistics, 'Vital statistics: population and health references tables', available at www.ons.gov.uk/peoplepopulationand community/populationandmigration/populationestimates/datasets/ vitalstatisticspopulationandhealthreferencetables, accessed 12 September 2017.

84 'Address of Dr. Sidney E. Goldstein on the need of a White House conference on family', Living, 1 (1939), 13-14.

85 US Department of Health, Education and Welfare, 100 years of Marriage and Divorce Statistics: United States, 1867-1967, HRA 74-1902 (Rockville, MD: Health Resource Administration, 1973); US Census Bureau, Births, Deaths, Marriages, and Divorces (Statistical Abstract of the United States, 2011), p. 96, available at www.cdc.gov/nchs/data/series/sr_21/ sr21_024.pdf, accessed 15 April 2019.

86 In 1946, debates in the House of Lords drew attention to the 'flood of cases' of divorce among servicemen and women that were putting pressures on the legal system - 'Services divorce delays', The Times, 27 March 1946, p. 8. The personal and domestic challenges of returning home from war was a familiar trope in post-war fiction: see Wilson, The Man in the Gray Flannel Suit. 
87 Final Report of the Denning Committee on Procedure in Matrimonial Causes, Cmd. 7024 (London: HMSO, 1946), cited in R. Cross, 'Final Report of the Denning Committee on Procedure in Matrimonial Causes', Modern Law Review, 10 (1947), 184-92.

88 Report of the Royal Commission on Marriage and Divorce, Cmd. 9678 (London: HMSO, 1956), cited in O. Kahn-Freund, 'Divorce Law Reform?', Modern Law Review, 19 (1956), 573-600, at p. 577.

89 O.R. McGregor, Divorce in England: A Centenary Study (London: William Heinemann, 1957), pp. 126, 152.

90 Cross, 'Final Report of the Denning Committee', p. 185.

91 A. T. M. Wilson, 'Some reflections and suggestions on the prevention and treatment of marital problems', Human Relations, 2 (1949), 233-52.

92 Report of the Royal Commission on Marriage and Divorce, pp. 7-8.

93 J. Lewis, The End of Marriage? Individualism and Intimate Relations (Cheltenham: Edward Elgar, 2001), p. 11. The term 'flight from commitment' is taken from B. Ehrenreich, The Hearts of Men: American Dreams and the Flight from Commitment (New York: Anchor Books, 1984).

94 For approaches to rebuilding life after the war, see Sir J. Marchant (ed.), Rebuilding Family Life in the Post-War World: An Enquiry with Recommendations (London: Odhams Press, 1945).

95 Mace, Marriage Crisis, p. 14.

96 Ibid., pp. 14-15. An organisation to promote family values 'for the advantage of the individual and the Nation State', the National Council on Family Relations was founded in America in 1938. The first issue of the Council's journal, Living, published in January 1939, focused largely on marriage.

97 Ibid., pp. 111, 131.

98 M. Stopes, Enduring Passion, 2nd edition (London: Putnam, 1929), pp. 1-11. This was a sequel to the widely popular Married Love, written primarily for couples during the early years of their marriage.

99 Stopes, Enduring Passion, pp. 151-2, 189-90. In both men and women, Stopes argued, disturbances of 'internal glandular balance' could be rectified with glandular extracts.

100 Stopes, Change of Life in Men and Women, p. 22.

101 Ibid., p. 1. In 1937, Macpherson Lawrie, a physician in psychological medicine at Queen Mary's Hospital in London, blamed modern transport for estranging husbands and wives and damaging 'domestic sentiment' - $\mathrm{M}$. Lawrie, Love, Marriage and Divorce (London: Methuen, 1937), pp. 185-8. See also R. Overy, The Morbid Age: Britain Between the Wars (London: Allen Lane, 2009). 
102 On decline narratives more generally, see Gullette, Declining to Decline.

103 W. Brown, Psychological Methods of Healing: An Introduction to Psychotherapy (London: University of London Press, 1938), pp. 158-60.

104 M. Macaulay, The Art of Marriage (London: Delisle, [1952] 1956), pp. 96-7. Macaulay placed the burden for maintaining marital fidelity largely on the wife: 'The husband who knows he will be warmly welcomed at home and warmly welcomed in the bed has no need to look elsewhere for reassurance that he is loved and appreciated.'

105 G. I. Manus, 'Marriage counseling: a technique in search of a theory', Journal of Marriage and the Family, 28 (1966), 449-53.

106 J. H. Wallis and H. S. Booker, Marriage Counselling: A Description and Analysis of the Remedial Work of the National Marriage Guidance Council (London: Routledge \& Kegan Paul, 1958), p. 39.

107 Ibid., p. 92.

108 Ibid., pp. 125-66, passim. The result was unknown in 33 per cent of cases.

109 Ibid., pp. 167-202, passim.

110 Ibid., pp. 270-4.

111 J. H. Wallis, The Challenge of Middle Age (London: Routledge \& Kegan Paul, 1962), p. vii.

112 Ibid., pp. 1-13.

113 Ibid., p. 89.

114 Ibid.

115 Ibid.

116 Studies of the drivers of marriage guidance in the mid-twentieth century include: J. Lewis, 'Public institution and private relationship: marriage and marriage guidance, 1920-1968', Twentieth Century British History, 1 (1990), 233-63; A. Harris, 'Love divine and love sublime: the Catholic Marriage Advisory Council, the marriage guidance movement and the state', in A. Harris and T. Jones (eds), Love and Romance in Britain, 1918-1970 (Basingstoke: Palgrave Macmillan, 2015), pp. 188-224; T. Chettiar, "More than a contract": the emergence of a state-supported marriage welfare service and the politics of emotional life in post-1945 Britain', Journal of British Studies, 55 (2016), 566-91.

117 Wallis and Booker, Marriage Counselling, Appendix B, p. 100.

118 Report of the Royal Commission on Marriage and Divorce, paras 45 and 46; Jaques, 'Death and the mid-life crisis', pp. 51-6.

119 K. Bannister, A. Lyons, L. Pincus, J. Robb, A. Shooter and J. Stephens, Social Casework in Marital Problems: The Development of a Psychodynamic Approach (London: Tavistock Publications, 1955), p. 28.

120 Ibid., pp. 7-8. 
121 Conversion of the 'vicious circle' into a 'beneficent spiral' was achieved in the case of Mr and Mrs Rivaux - ibid., pp. 67-78, at p. 78. For reference to the 'primary family unit', which included children, see ibid., p. 145.

122 Dicks, Marital Tensions, pp. 1-2.

123 Ibid., p. 42.

124 H. V. Dicks, 'Clinical studies in marriage and the family: a symposium on methods', British Journal of Medical Psychology, 26 (1953), 181-96.

125 Dicks, Marital Tensions, pp. 236-53. On the novelty of Dicks's approach, see G. Gorer, 'Book Review', International Journal of Psycho-Analysis, 49 (1968), 107-9.

126 Dicks, 'Clinical studies in marriage and the family'.

127 Ibid., p. 195.

128 M. Hilliard, A Woman Doctor Looks at Love and Life (New York: Doubleday, 1957), pp. 106-7, 112, 146; Papers of Viola Klein, University of Reading, MS 1215/29/1/762. On Hilliard's popular advice literature, see K. Mendes, 'Reading Chatelaine: Dr Marion Hilliard and 1950s women's health advice', Canadian Journal of Communication, 35 (2010), 515-31.

129 Dicks, 'Clinical studies in marriage and the family', p. 195.

130 Dicks, Marital Tensions, p. 225.

131 Beck and Beck-Gernsheim, The Normal Chaos of Love, p. 67.

132 Ibid., p. 6.

133 Marriage guidance was shaped explicitly by the work of child guidance clinics, which had been established on both sides of the Atlantic during the interwar years and which regarded juvenile delinquency and other behavioural disorders as partly the product of domestic difficulties and broken homes.

134 Hauser, Look Younger, Live Longer, pp. 188-97. 